\title{
Water and Sanitation Services: From National Government to County Governments
}

\author{
By Eng. Claude Busieney ${ }^{1}$ \\ 1.Lecturer Masinde Muliro University of Science and Technology, Department of Civil and Structural Engineering.(MMUST) \\ P.o Box 2353-50100 Kakamega.
}

\begin{abstract}
Water and sanitation services in Kenya have undergone several reforms in the recent years. Prior to 2002 the water and sanitation services were under the control of the ministry of water. In 2002 a new water act was enacted. This created several institutions both at National and Regional level. The water were under the Water Service Boards which were regional entities under the water act of 2002 . However in 2010 a new Constitution of Kenya was enacted. Under the new constitution the water and sanitation services are domiciled in the county governments. This paper looks at the evolution of water and sanitation services in Kenya to date.
\end{abstract}

Keywords - Constitution of Kenya, Kenya Gazette, Water Act and Water Bill .

\section{THE PAPER}

Prior to 2002 the water and sanitation services were mainly the preserve of the National government.

These services were either provided by the local authorities, District Water officers or by National Water and Pipeline Corporation(NWCPC) that was running several schemes across the country. The biggest of these schemes was supply of water and sanitation services to Mombasa city. Other major towns that were operated by NWCPC included Nakuru, Gilgil, Kisii, Malindi, Kwale, Voi, Kerugoya, Embu, Karatina,e.t.c.

However in 2002 a new water act was enacted.

The Water Act 2002 separated the role of policy formulation, regulation, water resource management and water services by creating various but complimentary institutions to implement and manage the reforms in the water sector. The Water Sector Reforms aimed at ring fencing the water revenues for ploughing back to the sector for enhanced and sustainable service delivery

These institutions were supposed enhance accountability for water resource management through a structured mechanism of checks and balances. The reforms also decentralized water and sanitation services delivery to reional levels to improve the quality of service provided.

The institutional framework developed is as shown below:

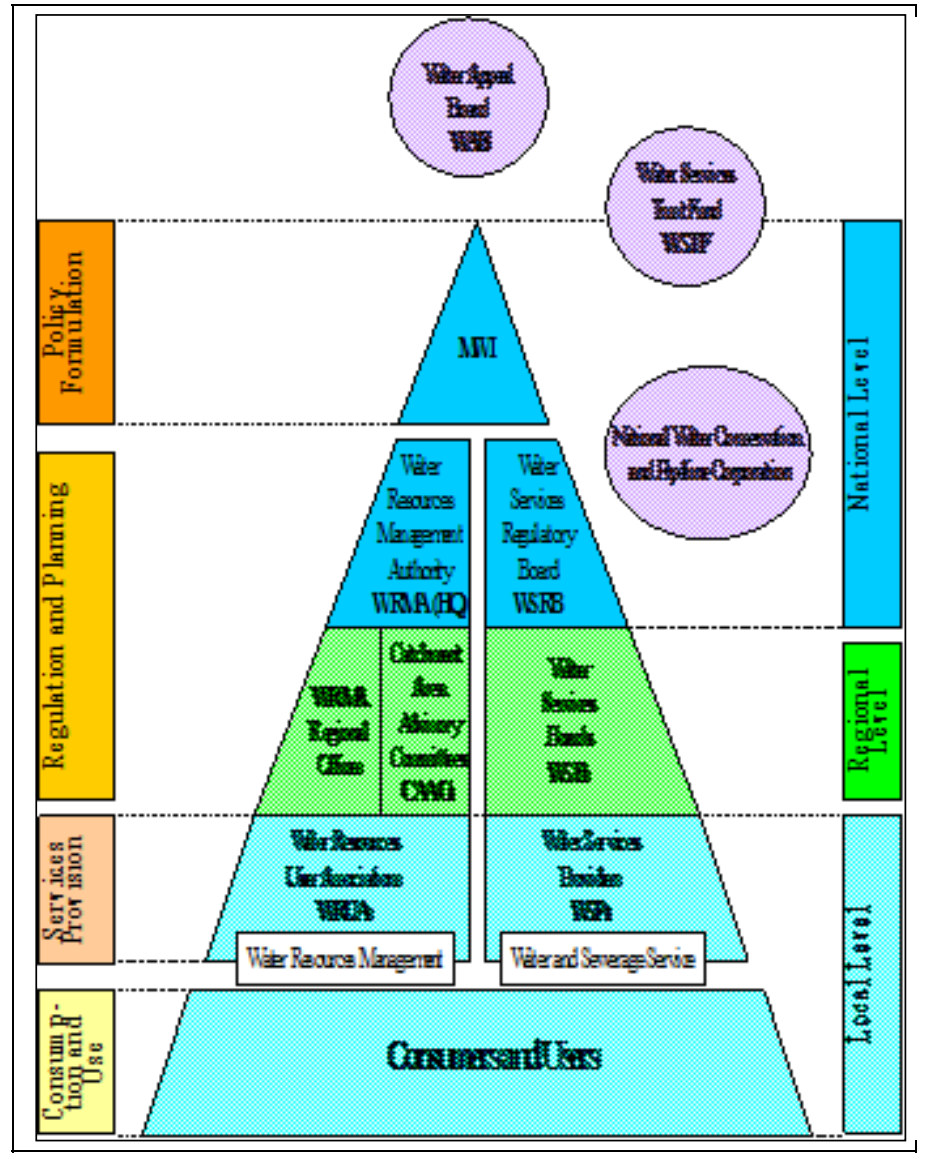

These institutions are described as below.

\begin{tabular}{|c|c|}
\hline Institution & Role \\
\hline $\begin{array}{c}\text { Ministry of } \\
\text { Environment, Water } \\
\text { and Natural Resources } \\
\text { (MEWNR) }\end{array}$ & $\begin{array}{c}\text { To formulate policy and provide } \\
\text { oversight within sector }\end{array}$ \\
\hline $\begin{array}{c}\text { Water Services Trust } \\
\text { Fund (WSTF) }\end{array}$ & $\begin{array}{c}\text { To finance water services to the } \\
\text { underserved }\end{array}$ \\
\hline $\begin{array}{c}\text { Water Appeal Board } \\
\text { (WAB) }\end{array}$ & To hear and determine disputes \\
\hline $\begin{array}{c}\text { Water Services } \\
\text { Regulatory Board } \\
\text { (WASREB) }\end{array}$ & $\begin{array}{c}\text { To regulate matters related to water } \\
\text { services }\end{array}$ \\
\hline $\begin{array}{c}\text { Water Service Boards } \\
\text { (WSB) }\end{array}$ & $\begin{array}{c}\text { Regional body responsible for } \\
\text { regulation and planning of water } \\
\text { services }\end{array}$ \\
\hline
\end{tabular}




\begin{tabular}{|c|c|}
\hline $\begin{array}{c}\text { Water Service } \\
\text { Providers (WSP) }\end{array}$ & $\begin{array}{c}\text { To provide water services under } \\
\text { license from the WSBs }\end{array}$ \\
\hline $\begin{array}{c}\text { Water Resources } \\
\text { Management Authority } \\
\text { (WRMA) }\end{array}$ & $\begin{array}{c}\text { To plan, regulate and manage water } \\
\text { resources }\end{array}$ \\
\hline $\begin{array}{c}\text { Catchment Area } \\
\text { Advisory Committees } \\
\text { (CAAC) }\end{array}$ & $\begin{array}{c}\text { Regional body set up to advise WRMA } \\
\text { on the management of water resources }\end{array}$ \\
\hline $\begin{array}{c}\text { Water Resource Users } \\
\text { Associations (WRUA) }\end{array}$ & $\begin{array}{c}\text { Local body set up by water users to } \\
\text { enable communities and water users to } \\
\text { participate in water resource } \\
\text { management }\end{array}$ \\
\hline $\begin{array}{c}\text { National Water } \\
\text { Conservation and } \\
\text { Pipeline Corporation } \\
\text { (NWCPC) }\end{array}$ & $\begin{array}{c}\text { Development and management of state } \\
\text { assets for bulk water supply }\end{array}$ \\
\hline $\begin{array}{c}\text { Kenya Water Institute } \\
\text { (KEWI) }\end{array}$ & $\begin{array}{c}\text { KEWI is responsible for training and } \\
\text { research in water and related matters }\end{array}$ \\
\hline
\end{tabular}

On August 25th 2010, a new constitution of Kenya (CoK) was enacted.

The CoK 2010 spells out, among other provisions that (a) water is vested in the people, (b) water (supply) and sanitation (services) is a right, (c) development of water resource is a function of the national government, along with implementation of specific national government policies on natural resources, taking into account recommendations of the National Land Commission (NLC); and (d) environmental conservation as well as county public works and water and sanitation services provision including storm water management is the function of county governments.

In the new constitution therefore water and sanitation services is now a function of the county governments.

In a special Kenya Gazette issue of 9th August 2013 (Kenya Gazette No. 116) the Transition Authority approved the transfer of Water and Sanitation Services to the counties.

This set the stage for a protracted struggle between the county governments and the water service Boards who previously managed water and sanitation services through Water Service Providers. This provided them with revenues for their operations and personal emoluments. The Boards also received grants from National Government.

Also funds for infrastructure development was channelled through the Boards by respective donors.

In the new dispensation the more likely scenario is that infrastructure development for water and sanitation services will be carried by the county governments. This will mean that the county governments will need to employ professional for the developments and implementation of the requisite infrastructure.

A new water act 2013 has been proposed.

Under the proposed water act the following institutions will be developed
1.Water Resources Regulatory Authority This will deal with regulatory management and use of water resources

2. Water Works Development Boards. This deal with infrastructure development for water and sanitation services. 3. Water Services Regulatory Commission. This will replace the current WASREB and deal with requlation of water and sanitation services.

4. Water Service Providers. This will deal with provision of water and sanitation services and and likely to be county based.

5. Water Sector Trust Authority. This will deal mainly with funding of small community based projects.

6. Water Tribunal. This will act as a tool of dispute resolution in the water sector.

7. National Water Storage Authority. This deal mainly with water conservation and will take over most of the functions currently performed by NWCPC.

As can be seen from the proposed water act 2013 the Water Works Development Board may be in conflict with the provision of the constitution on the devolved functions.

A further new development was the establishment of a task force on Parastatal Reforms by H.E the President on 23rd July 2013.

This task force came up with radical recommendation on way forward for parastatals. Some parastatals will have to wind up to give way to Government Investment Corporation. Others will be merged.

The fate of the Water Boards according to this report will be determined by National Government and the County Governments.

Brief Biography of presenting author:

Eng. Claude K. Busieney is a lecturer at MMUST. He holds an MSc. from the university of Birmingham UK. $\mathrm{He}$ is a registered professional engineer (EBK) and Corporate Member of Institution of Engineers of Kenya. He has over 25 years of experience in the water sector covering planning, design, tender documentation, construction supervision of dams, management and maintenance of water supply, and sewerage/sanitation. He has carried out procurements processes both for Consultancies and Construction Works under World Bank and Kfw of Federal Republic of Germany. He has also implemented projects under JICA funding. He has a been a World Bank project co-ordinator and has vast experience in project management.

\section{References}

- New Constitution of Kenya of 2010.

- Water Act 2002 of Kenya.

- Proposed Water Bill of Kenya of 2013.

- Kenya Gazette No. 116 